\title{
ECOLOGICAL ECONOMICS AND HUMAN ECOLOGY
}

\author{
Arran Gare \\ Philosophy and Cultural Inquiry \\ Swinburne University
}

\section{CONTEXTUALIZATION}

\section{I.I. The Present Predicament}

While economic theory has been enormously influential since the eighteenth century, the level of dominance of culture, politics and ethics gained by it in the last few decades is unprecedented. Not only has economic theory taken the place of political philosophy and ethical discourse and imposed its own concepts and image of society on other social sciences, it has redefined the natural sciences through its own categories as nothing but instruments of production, investment in which is to be judged in terms of its profitability. No longer does economics justify its claim to be a science on its supposed success at modeling itself on physics; it stands in judgement of physics and demands of physicists that they justify themselves in economic terms. Literature and the arts have also been redefined, as part of the entertainment industry, also to be judged in terms of profitability and contribution to GNP. Rationality itself has been redefined by rational choice theorists to accord with the economists' model of economic choice within the market. There is no common good, participation in the pursuit of which could give meaning to people's lives; according to rational choice theorists there is only the satisfaction of diverse individual subjective preferences (Amadae, 2003, p.IIIff.). Governments almost everywhere (apart from New Zealand and some countries in South American where such policies have now lost all credibility) are redefining their relationship to their citizens through the categories of economics (Osborne \& Gaebler, 1993) and under the influence of economists (and the pressure of transnational corporations, the IMF, the World Bank and the WTO) are imposing market relations on virtually every facet of social, political and cultural life. This involves deregulating markets, freeing trade, removing impediments to capital mobility, privatizing public assets, applying the "user pays" principle to allocate resources, applying economic principles to government and measuring success in purely "economic" terms. Even after whole countries have been thrown into economic chaos, as vast numbers of people are losing their livelihoods, welfare institutions are being dismantled, democracy is being undermined and, most ominously, the global

Handbook of Whiteheadian Process Thought Volume 1, Ed. Michel Weber and Will Desmond, (Frankfurt: Ontos Verlag, 2008). Pp.161-176. 
ARRAN GARE: ECOLOGICAL ECONOMICS AND HUMAN ECOLOGY

eco-system is being degraded, there has been only weak resistance to these developments, apparently because the majority of humankind, or at least most of those with any power, have come to see themselves and their everyday relationships, both to other people and to nature, through the categories of economics. Politicians in particular, appear oblivious to any other way of conceiving the world.

These might appear to be extreme claims; but this is because economics has been so successful in colonizing the way people think in their everyday lives that it is difficult to appreciate the uniqueness of present culture. One way to highlight this uniqueness is to consider one country, Britain, a century ago (that is, when Alfred North Whitehead was involved in politics). It is generally assumed that Britain at that time was dominated by much the same thinking that dominates the present. Not so. The most powerful political and cultural force at the time was social liberalism (or New Liberalism), a movement largely inspired by the Idealist philosopher T.H. Green (1836-I882) (Boucher, I997, p.viiiff.). Green had attacked the notion that freedom is gained through freely entered contracts and that the State's primary role is to protect property and enforce contracts, arguing that contracts made between people with unequal power, as between employees and employers, could not be called free (Green, I986, I94ff.) Inspired by Kant, Fichte and Hegel, Green argued instead that freedom is gained by participating in democratic communities united in the quest for a common good; most importantly, the quest to develop people's potential to participate in community life. "When we speak of freedom" he wrote, "we mean a positive power or capacity of doing or enjoying something worth doing or enjoying, and that, too, something that we do or enjoy in common with others." Green continued: "When we measure the progress of a society by its growth in freedom, we measure it by the increasing development and exercise on the whole of those powers of contributing to social good with which we believe the members of the society to be endowed; in short, by the greater power on the part of the citizens as a body to make the most and best of themselves" (Green, I986, p.199). The highest good, never fully realized, is not increase in GNP but human perfection pursued through institutions. As Green put it, "There are arts and institutions and rules of life, in which the human spirit has so far incompletely realized its idea of a possible Best; and the individual in whom the idea is at work will derive from it a general injunction to further these arts, to maintain and, so far as he can, improve these institutions" (Green, 2003, p.43I). The State's mission is to nurture the potential of its citizens to live the best possible life by enabling them to participate in these projects.

From the i88os onwards social liberals, inspired directly or indirectly by Green's philosophy, undertook a crusade against poverty and ignorance as barriers to freedom

Handbook of Whiteheadian Process Thought Volume 1, Ed. Michel Weber and Will Desmond, (Frankfurt: Ontos Verlag, 2008). Pp.161-176. 
and democracy, argued for the rights of women to be educated and to vote, defended the role of the State to control the economy, and opposed imperialism. "The State arises" David Ritchie wrote, "to ensure that the individual shall be fully realized, chiefly through his own conscious action. The State guarantees him his individuality, which Society with its self-seeking struggle of competitors tends to efface" (Ritchie, I902, p.I55). Social liberals demonstrated empirically that poverty was socially produced and systemic in nature, not the fault of individuals. L.T. Hobhouse and J.A. Hobson argued that wealth was created by society rather than individuals, and that the State owed its citizens the means of maintaining a civilized life, a debt, Hobhouse argued, "not adequately discharged by leaving him to secure such wages as he can in the haggling of the market" (Hobhouse, I9I I, p.i64). Hobhouse also called for wealth taxes to "quench the antisocial ardour for unmeasured wealth, for social power and the vanity of display" (p.20I). The older laissez-faire liberalism was deemed to be theoretically and practically obsolete. The inequality and poverty engendered by laissez-faire economics were seen to be bad not simply on utilitarian grounds, but because it made it impossible for people to develop their potential and function effectively as citizens of a democracy. Apart from calling for intervention in the economy to eliminate poverty, social liberals campaigned for free public education, set up the Workers' Educational Association to educate the working class and called for free public libraries and galleries. Reading books and contemplating works of art were not seen as mere entertainment but as part of self-education and the development of oneself as a person, the supreme duty of people as citizens of a democracy (Murdoch, I903, p.236f.).

While social liberalism was inspired by philosophers, it was also developed by political theorists and economists. While John Hobson was the major economist in this tradition in the first decades of the twentieth century, John Maynard Keynes to some extent continued the tradition of social liberalism. Apart from his economic theories concerned to show how depressions can be avoided through State involvement in the economy, Keynes, through his involvement in negotiating the Bretton Woods Agreement, strove to create a world order in which democratic States could control their own markets and their own destinies and cultivate higher ends than avarice.

The triumph of economics to its present despotic position was not the triumph of economic science as such, but the triumph of neo-classical economics - and the revival of Social Darwinism. Neo-classical economics is based on the analysis of market behaviour, assuming isolated, utility maximizing economic agents with diminishing marginal utilities for each commodity. Prices are supposedly determined by supply and

Handbook of Whiteheadian Process Thought Volume 1, Ed. Michel Weber and Will Desmond, (Frankfurt: Ontos Verlag, 2008). Pp.161-176. 
ARRAN GARE: ECOLOGICAL ECONOMICS AND HUMAN ECOLOGY

demand schedules the shape of which is determined by diminishing marginal utility, with prices supposedly determined by the intersection of these schedules, indicating that it is at this price with these quantities that demand and supply will be equal. At this equilibrium point the value of the marginal item will be exchanged for its value equivalent, with all other items of this kind exchanged in the market resulting in a value gain for those involved in the exchange. Value is treated as not something objective but as something subjective, revealed by what people are willing to pay. The economy is then represented as a circular flow of money between business enterprises and households (or the public) with business paying for land, labour and money (as rent, wages and salaries, and interest respectively) and gaining profits through its entrepreneurial efforts, while the households pay for goods and services. Neo-classical economics has its roots in the work of Jevons (in England), Menger (in Austria) and Walras (in Switzerland and France), each developing their ideas in the I87os (at about the same time that Green was elaborating his ideas) (Pibram, p.277ff.). Jevons set out to rebuild economics as "the mechanics of utility and self interest" (Jevons, I924, p.2I). While this idea has been influential, it was the mathematically oriented Walrasian school with its model of general equilibrium which eventually prevailed. The conclusions drawn from the work of this school, that it is through the free operation of the market that scarce resources will be most efficiently distributed between unlimited wants, has been supported also by the less mathematically oriented and more evolutionary Austrian school deriving from Menger, promoted most vigorously by Friedrich von Hayek.

How did this tradition triumph? Keynesian economics, advancing the insights of Hobson and challenging the cozy conclusions of neo-classical economics that free markets will tend to an equilibrium in which there will be full employment of labour (unemployment on this model being explained by the unwillingness of labour to accept lower wages), had been vindicated by the Great Depression and the success of solutions he provided for it. But while Keynesian economics was widely embraced, social liberalism was in decay. In USA Keynes' ideas were reinterpreted through neoclassical marginalist theory, and this paved the way for the revival of neoclassical economics and the almost complete eclipse of Keynesian thought (Harcourt, 1982, p. $355 \mathrm{ff}$.). This occurred in the I $970 \mathrm{os}$, and neo-classical economics has dominated ever since. This ascendancy has been associated with the privileging of abstract mathematical models of the market which has had the effect of excluding the general population from participation in economic debates. Neo-classical economics, elaborated into the ideology of neo-liberalism (or more accurately, managerialist

Handbook of Whiteheadian Process Thought Volume 1, Ed. Michel Weber and Will Desmond, (Frankfurt: Ontos Verlag, 2008). Pp.161-176. 
market fundamentalism) has come to almost completely dominate public policy formation. This is the basis of our present predicament.

\subsection{The Challenge of Ecological Economics to Neo-Classical Economics}

Neo-classical economics has not gone unchallenged. In fact there has been a bewildering array of challenges to it, with both alignments and conflicts between the challengers. Basic assumptions have been questioned even within neo-classical economics. Criticisms have ranged from pointing out that even in terms of their own assumptions, neoclassical economists have not been able to show that there is any reason for markets to move to an optimal equilibrium, to questioning the central assumptions about markets, human nature and society together with assumptions about the nature of science and scientific explanation on which neo-classical economics is based (Gowdy and Erikson, 2005, p.208). Criticisms have been leveled at the characterization of economic actors as egoistic utility maximizers and objections have been made to analyses of factor markets on the assumption that these are essentially the same as markets for goods and services. In relation to the labour market, Green's point, that employers and employees have unequal power in the marketplace, has been reiterated (Nell, I980, p.23f.). The assumption of diminishing marginal productivity of capital, required to show that there is an equilibrium point in capital markets, has been shown to be highly problematic. Developments within mathematical economics associated with complexity theory have revolutionary implications. Brian Arthur focused on "increasing returns", that is, markets where success feeds on itself to generate more success (Arthur, 1994). In such circumstances, which are normal rather than exceptional, there is no tendency towards equilibrium, and it is necessary to treat the economy as much more dynamic, creative and destructive, than neo-classical economists have been prepared to acknowledge. Complexity theory also gives a place to emergence, implying limits to the reductionism assumed by neo-classical economics. By showing that present conditions are dependent upon the paths which have generated them, such work requires economists to acknowledge the importance of history (Ormerod, 1994). Arthur's work has effectively vindicated the historical, institutionalist, evolutionary economics that neoclassical economics first displaced and then almost obliterated (Hodgson, 200I). It has also been pointed out that despite the acknowledgement of land as a factor of production and Jevons' appreciation of the limits to energy resources, the concepts of neo-classical economics virtually excluded nature from consideration (Groh and Sieferle, I980). The neo-classical model of economic growth is inconsistent with the second law of thermodynamics and oblivious to the dynamics of eco-systems, including the global eco-system. The rapid destruction of resources and eco-systems for short

Handbook of Whiteheadian Process Thought Volume 1, Ed. Michel Weber and Will Desmond, (Frankfurt: Ontos Verlag, 2008). Pp.161-176. 
ARRAN GARE: ECOLOGICAL ECONOMICS AND HUMAN ECOLOGY

term profit increases can be shown to be entirely rational on neo-classical assumptions, suggesting something irrational in neo-classical characterizations of rationality. It has also provided further reasons for investigating the relationship between the dynamics of economies, other social formations, and the rest of nature. Most importantly, this justifies a greater concern with the relationship between the dynamics of economies and the dynamics of eco-systems, particularly the dynamics of the global economy and local ecosystems (Bunker, 1985). In doing so, these critiques of mainstream economics provide overwhelming reasons for reviving fundamental questions about the nature of the knowledge and what it is to be a science.

It is here that major problems arise, however. What I have presented is a very schematic account of arguments against neo-classical economic theory. As noted, there is no consensus among the opponents of neo-classical economics. The political economy movement led by Joan Robinson attempted to revive a left Keynesianism, and failed (Kregel, I975; Nell, 1980). Marxist critics divided on the most basic issues of what Marxism stands for (Roosevelt, 1975). Students in France have sparked a global movement for post-autistic economics, but they are clearer on what they oppose than what they stand for. Institutionalists attempted to chart an alternative path to mainstream and Marxist economics (Mirowski, 1986). This movement had some success, but those involved in this revival are finding that they have to retrace the history of historical and institutional economics and confront the problems within it which led to its eclipse by neo-classical economics. It is necessary to meet again Menger's challenge to historical economics and the limits of Thorstein Veblen's efforts to develop institutionalist economics (Hodgson, 200I, p.75ff., p.I5of.). Attempts to make economics into an evolutionary science have forced institutional economists to confront disputes within evolutionary science (Mirowski, I994; Hodgson, I999). Such developments align institutionalist economists with some of the economists grappling with environmental problems (Söderbaum, 2000, p.2Iff.). Not that there is any consensus here. There is a division between the environmentalist economists who have attempted to extend neo-classical economics to deal with environmental problems, attempting to incorporate "externalities" into the market, and ecological economists who have attempted to characterize economics as part of the broader science of ecology (Spash, 1999). This has presented another problem, since ecology is by no means a unified discipline. As in economics, divisions among ecologists extend to conflicts about what is knowledge and what is science (Levins and Lewontin, 1985). It might seem that complexity theory provides the necessary bridge between mainstream economics, institutional economics, ecological economics, ecology and evolutionary theory on which a new synthesis might be built; but "complexity" defines a problem

Handbook of Whiteheadian Process Thought Volume 1, Ed. Michel Weber and Will Desmond, (Frankfurt: Ontos Verlag, 2008). Pp.161-176. 
rather than the solution, and there is a range of rival research programs addressing this problem (Gare, 2000a). Mirowski, a proponent of institutionalist economics, has severely criticized complexity theory as a new phase in mechanistic thought (Mirowski, 2002).

Despite problems within it, it is ecological economics which is now emerging as the most potent opposition to neo-classical economics. It is ecological economics which addresses the most profound failure of neo-classical economics, the failure to deal adequately with resource depletion and environmental destruction locally, and more importantly, globally (Constanza, I99I, Söderbaum, 2000). In doing so, it has drawn on the whole range of arguments against mainstream economics, including the relationship between economics and other sciences (Røpke, 2004, 2005). All problems and debates within and over economics have thereby been brought into focus. As two proponents of ecological economics proclaimed, human ecology is "the only heterodox school of economics focusing on both the human economy as a social system, and as a system embodied in the biophysical universe, and thus both holistic and scientifically based," going on to claim that "ecological economics is poised to play a leading role in recasting the scope and method of economic science" (Gowdy and Erickson, 2005, p.207). In doing so, ecological economics simultaneously raises all the most basic questions about what is knowledge, what is science, what is the nature of physical existence, of life, of humanity, of society and of the individual. While this has generated a range of debates, ecological economics suffers from a weak identity (Røpke, 2005, p.286). The challenge it faces is to hold together as a radical challenge to mainstream economics in virtually every respect.

\subsection{Economics and Philosophy}

Given the chaotic state of debates in economics and the challenges confronting ecological economics, we need to examine the history of both economics and philosophy to bring into the open unexamined philosophical assumptions befuddling these debates. It is also necessary to see what happened to social liberalism and why it lost its impetus. To begin with, it is necessary to look at epistemology, most importantly, the development of logical positivism and the influence of its vision of science. But it is also necessary to look behind this to the rivalry between broader traditions of thought about humanity, society and politics and how this has been affected by logical positivism.

Logical positivism emerged as part of the new tradition of analytic philosophy which developed in opposition to the Idealism inspired by Green. Logical positivists

Handbook of Whiteheadian Process Thought Volume 1, Ed. Michel Weber and Will Desmond, (Frankfurt: Ontos Verlag, 2008). Pp.161-176. 
ARRAN GARE: ECOLOGICAL ECONOMICS AND HUMAN ECOLOGY

were concerned to invalidate not only the claims but the whole project of metaphysics, and the metaphysics its proponents usually had in mind were the metaphysics of Idealism. So, whether intentionally or not, logical positivism was centrally involved in undermining the ideals about life and society and how society should be organized proposed by Green and the social liberals he inspired. However, this was not simply a matter of undermining Green's philosophy and influence - an influence associated not only with social liberalism but the rise of the welfare state and social democracy. It was also a matter of facilitating a revival of the ideas that Green and the British Idealists had been concerned to overcome. To begin with, it is clear that the triumph and influence of logical positivism greatly helped the advance of neo-classical economics. While von Hayek was not a logical empiricist, the influence of logical positivism is clearly evident in the characterization of economics as a science by the major proponent of neo-classical economics and neo-liberalism in USA, Milton Friedman (Friedman, 1953, Part I; Hollis and Nell, 1979). Such logical positivism was later assumed unconsciously by economists who attempted to develop computer models of the economy. What mattered was constructing mathematical models from which predictions could be made and tested, even if the predictions were all wrong; all other forms of intellectual inquiry were held to be "unscientific" and not worthy of being taken seriously. This means that ideas deriving from social liberalism could easily be dismissed.

Logical positivism also facilitated the revival of a broader tradition of thought that the social liberals had opposed: social Darwinism. If there was one philosopher the British Idealists were opposed to it was Herbert Spencer. Spencer had coined the phrase "survival of the fittest" which had been embraced by Darwin. Spencer used this idea to present a vision of evolutionary progress driven by the struggle for survival in which the fitter defeat and dominate the weaker. Spencer, who was also editor of The Economist, argued that the free market economy in which individuals struggle against each other to satisfy their insatiable appetites is the basis for continued evolutionary progress (Spencer, I969, p.I4Iff.; Spencer, 1973, p.73). For this to work, the State should withdraw support from the losers in this struggle within the market, since this will interfere with the mechanism driving evolutionary progress. Competition between countries should also become economic competition. The role of the State in society is merely to keep in place the rules of the market, most importantly, protecting property. This political philosophy was presented as part of the scientific vision of the world, or, in the language of Spencer's friend, John Tyndall (and fellow member of the "X Club" which was attempting promote science as the core of education and of culture) as part

Handbook of Whiteheadian Process Thought Volume 1, Ed. Michel Weber and Will Desmond, (Frankfurt: Ontos Verlag, 2008). Pp.161-176. 
of "scientific materialism", a term Tyndall coined in I868 (Barton, I987; Harman, 200I, p.I99). While this vision of the world is not explicitly invoked by neo-liberals, it is presupposed by them and neo-liberalism gained immense impetus through the revival of social Darwinism (Lewontin et.al, I984), largely made possible through the defence by logical empiricists of reductionist forms of explanation. The revival of social Darwinism reached its highest point with the development of socio-biology in the I970s where social behaviour was explained as nothing but the effect of the struggle for survival by selfish genes. Explicitly aligning himself with Spencer, the foremost sociobiologist, Edward O. Wilson, argued that "the individual organism is only their vehicle, part of an elaborate device to preserve and spread them with the least possible biochemical perturbation (Wilson, I975, p.3). To some extent the triumph of neoclassical economics is merely a manifestation of the revival of Spencer's social Darwinism.

Logical positivism had its greatest impact by undermining the philosophical movements which challenged the assumptions of social Darwinism. What were these movements? There was more to Anglophone philosophy in the late nineteenth century and early twentieth century than the opposition between social Darwinism and Idealism. "Scientific materialism" had already met with opposition within physics from Clerk Maxwell and his colleagues (Harman, 200I, p.I9gff.). Maxwell's work, developing field theory in physics, was one of the high points in the tradition, ultimately inspired by Leibniz and Boscovich, concerned to overcome the mechanistic cosmology of the Newtonians. Maxwell was Einstein's hero, and the theories of relativity continued this tradition of thought. While Darwinian evolutionary theory was taken as vindicating scientific materialism, evolutional theory had originally been revived by opponents of Newtonian thought who had wanted to exalt humanity as the product of a creative nature (Richards, 2003, p.298ff.). There were tensions in both Spencer's and Darwin's theories, and good reason to draw different political conclusions than those drawn by Spencer from the theory. Darwin himself eventually drew different conclusions (Richards, 2003, p.547ff.). While disputes in these areas were underway, logic was being revolutionized by the importation into it of the algebraic techniques developed within mathematics. While logical positivism had drawn heavily on this new logic, particularly as it had been developed by Frege, in USA Charles Sanders Peirce advanced and utilized symbolic logic to different ends to justify speculative thought (as abduction) and to develop a revised form of Objective Idealism incorporating a radicalized form of evolutionary theory (Peirce, 1955, p.322). In Britain, some of Green's followers, most notably Ritchie, were attempting to

Handbook of Whiteheadian Process Thought Volume 1, Ed. Michel Weber and Will Desmond, (Frankfurt: Ontos Verlag, 2008). Pp.161-176. 
ARRAN GARE: ECOLOGICAL ECONOMICS AND HUMAN ECOLOGY

advance Idealism by synthesizing it with Darwinian evolutionary theory (Ritchie, I893, pp.38-76). While this synthesis provided some support to the social liberals, in general, evolutionary theory was held to be incompatible with Idealism and political theorists such as Hobhouse (who had been influenced by Green) and the economist Hobson felt that nature was inadequately appreciated in Idealism. During the First World War they came to believe the Hegelian idea of the State was responsible for German militarism (Clarke, 1978, p.193) and, distancing themselves from Idealism, moved towards a new form of non-reductionist naturalism giving a place to emergence. This was being supplied by Samuel Alexander who had attended Balliol College when Green was in residence, and who early in his career had attempted to reformulate Green's ethical philosophy to reconcile it with Darwin's evolutionary theory. Alexander embraced both the theories of relativity and Lloyd Morgan's notion of emergence and attempted to reformulate them into a new, evolutionary cosmology construing nature as essentially creative. Even more significant than its opposition to Idealism, logical positivism was important for having subverted this effort to develop a new, post-mechanist naturalism.

\section{THE IMPORTANCE OF WHITEHEAD}

It is against this background that we need to understand the significance of Whitehead. Whitehead was actively involved in politics. He was aligned with the social liberals of the Liberal Party although he also had some sympathy for the emerging Labour Party of which he later became a supporter (ESP igf.; Lowe, I985, p.313f.). He had been taught "that beauty, moral and aesthetic, is the aim of existence; and that kindness, and love, and artistic satisfaction are among its modes of attainment" (ESP I5) and he was concerned to uphold what he had been taught. He anticipated a future democracy in which "every man and every woman will be trained for a free intellectual life" (ESP I80). But at the same time he was a mathematician, a mathematical physicist, a logician and philosopher of mathematics and science, and a metaphysician. Whitehead was strongly influenced by Maxwell and concerned to interpret and advance his new physics. He was also a central figure in the development of the new symbolic logic, advancing Peirce's rather than Frege's conception of logic. He had been strongly influenced by Idealist philosophy, but believed it was necessary to go beyond their work, utilizing advances in the sciences and developments in logic. Like Peirce, he embraced evolutionary theory, but noted that this was in fact incompatible with scientific materialism (SMW I07). Matter, as conceived by scientific materialists, cannot evolve, he argued (echoing Peirce). Aligning himself with the work of Lloyd Morgan and Samuel Alexander, he worked to provide a new metaphysics which

Handbook of Whiteheadian Process Thought Volume 1, Ed. Michel Weber and Will Desmond, (Frankfurt: Ontos Verlag, 2008). Pp.161-176. 
would make the evolution of humanity from nature intelligible (SMW viii). His first major work directed towards a broader public, a work in which he also for the first time defended and sketched out a new cosmology and new metaphysics, Science and the Modern World, was a sustained critique of scientific materialism and its nihilistic implications. With a profound appreciation of the implications of the new logic, he exposed the failings of logical positivism, anticipating virtually all the arguments against it which were developed from the I950s to the I970s (PR 8; AI I24ff.; Gare, I999). Justifying speculative philosophy, Whitehead not only showed the incoherence of the ideas on which social Darwinism was based but provided foundations for advancing the ideas of the social liberals.

For Whitehead, scientific materialism represented the power of abstract thought. It was through a process of constructive abstraction that science arrived at simply-located bits of matter on the one hand, and minds on the other, enabling the physical world to be understood through mathematics. But as Whitehead noted:

The enormous success of the scientific abstractions, yielding on the one hand matter with its simple location in space and time, on the other hand mind, perceiving, suffering, reasoning, but not interfering, has foisted onto philosophy the tasks of accepting them as the most concrete rendering of fact. Thereby, modern philosophy has been ruined (SMW 55).

It is this which has led to the oscillation between dualists who accept mind and matter on equal terms, materialists who attempt to reduce mind to matter, and idealists who attempt to explain matter as a mental construct. But such thinking is contaminated by taking abstractions for concrete reality, without acknowledging or appreciating the level of abstraction involved. This is the "fallacy of misplaced concreteness". As Whitehead again noted, "this juggling with abstractions can never overcome the inherent confusion introduced by the ascription of misplaced concreteness to the scientific scheme of the seventeenth century" (SMW 55).

By this Whitehead was not suggesting that we could grasp reality in all its complexity if only we are prepared to eschew abstractions. The problem is that through the fallacy of misplaced concreteness scientists and philosophers, including Idealist philosophers, have remained wedded to a particular set of abstractions, blinded to the possibility of developing alternatives. As he argued:

You cannot think without abstractions; accordingly, it is of the utmost importance to be vigilant in critically revising your modes of abstraction. It is here that philosophy finds its niche as essential to the healthy progress of society. It is the critic of abstractions. A civilization which cannot burst through its current abstractions is doomed to sterility after a very limited period of progress (SMW 59).

Handbook of Whiteheadian Process Thought Volume 1, Ed. Michel Weber and Will Desmond, (Frankfurt: Ontos Verlag, 2008). Pp.161-176. 
ARRAN GARE: ECOLOGICAL ECONOMICS AND HUMAN ECOLOGY

Whitehead examined the Idealists, appreciating their insights into the limitations of scientific materialism but criticized them for being too divorced from the scientific outlook, failing "to connect, in any organic fashion, the fact of nature with their idealistic philosophies" (SMW 64). Nevertheless, Whitehead did not dismiss Idealist philosophy. In the "Preface" to PR he wrote of his own work: "if this cosmology be deemed successful, it becomes natural at this point to ask whether the type of thought involved be not a transformation of some main doctrines of Absolute Idealism onto a realistic basis" (PR xiii). Elsewhere, he defined the task of philosophy as the transcendence of the opposition between scientific materialism and the German tradition of philosophy. As he put it:

Leibniz introduced the alternative tradition that the entities, which are the ultimate actual things, are in some sense procedures of organization. This tradition has been the foundation of the great achievements of German philosophy. ... It should be the task of the philosophical schools of this century to bring together the two streams into an expression of the world-picture derived from science, and thereby end the divorce of science from the affirmations of our aesthetic and ethical experiences. (SMW I56)

Examining the various forms of confusion engendered by the efforts to escape the dualism of mind and matter by privileging one or the other, Whitehead proclaimed that "substance is for me the one underlying activity of realization individualizing itself in an interlocked plurality of modes. Thus, concrete fact is process" (SMW 70). The basic existents are not bits of matter but hierarchically ordered organisms which are more than the sum of their parts: "The concrete enduring entities are organisms, so that the plan of the whole influences the very characters of the various subordinate organisms which enter into it" (SMW 79). That is, he upheld the doctrine of emergence of Alexander and Lloyd Morgan. This provided the basis for a revolution in science.

Whitehead's work is relevant to economics in several ways. To begin with, he criticized economic science for having abstracted away from concrete reality and having mistaken its abstractions for concrete reality. As he put it:

It is very arguable that the science of political economy, as studied in its first period after the death of Adam Smith (1790), did more harm than good. It ... riveted on men a certain set of abstractions which were disastrous in their influence on modern mentality. It de-humanised industry. [A]ll thought concerned with social organization expressed itself in terms of material things and of capital. Ultimate values were excluded (SMW 200, 202f.).

Handbook of Whiteheadian Process Thought Volume 1, Ed. Michel Weber and Will Desmond, (Frankfurt: Ontos Verlag, 2008). Pp.161-176. 
Beyond this, Whitehead exposed the illusions underlying Herbert Spencer's social Darwinism with its glorification of competition. This theory had "directed almost exclusive attention to the aspect of struggle for existence in a fixed environment" (SMW 205). Due to this abstraction, Whitehead, pointed out: "The watchwords of the nineteenth century have been, struggle for existence, competition, class warfare, commercial antagonism between nations, military warfare. The struggle for existence has been construed into the gospel of hate" (SMW 205). Freed from the limitations of this abstraction, evolutionary theory has different implications: "The full conclusion to be drawn from a philosophy of evolution is fortunately of a more balanced character. Successful organisms modify their environment. Those organisms are successful which modify their environments so as to assist each other" (SMW 205). At the same time, Whitehead attacked "the Gospel of Uniformity" (SMW 206) and defended "the power of wandering" (SMW 207). "Physical wandering is still important" Whitehead averred, "but greater still is the power of man's spiritual adventures - adventures of thought, adventures of passionate feeling, adventures of aesthetic experience" (SMW 207). He defended diversity, arguing "Other nations of different habits are not enemies: they are godsends" (SMW 207).

Finally, Whitehead offered a new set of abstraction which, overcoming the dualisms generated by the triumph of scientific materialism, allowed humans to be understood as creative participants within nature within which values are intrinsic. Through this cosmology, Whitehead was able to offer a strong defence of cooperation in the pursuit of the common good, the cultivation of individuality and the pursuit of the higher ends the social liberals had sought to uphold (SMW 206). In a later work Whitehead analysed the loss of freedom associated with the industrial system where: "There only remain iron-bound conditions of employment and trivial amusements of leisure" (ESP I66). He called for economic statesmanship to recreate the conditions for freedom, individuality and variety of opportunity for useful activity "that the great commercial corporations are setting themselves to destroy" (ESP I69). Whitehead's new cosmology not only provided a defence of the ideals of social liberalism, it provided an alternative characterization of science to logical positivism. In doing so it provided the basis not only for criticizing both social Darwinism and neo-classical economics, but guidance for overcoming the one-sided abstractions of these traditions of thought, for building a new kind of science on more adequate abstractions, a science which could analyse the relationship between humans in the context of nature.

Handbook of Whiteheadian Process Thought Volume 1, Ed. Michel Weber and Will Desmond, (Frankfurt: Ontos Verlag, 2008). Pp.161-176. 
ARRAN GARE: ECOLOGICAL ECONOMICS AND HUMAN ECOLOGY

3. THE HISTORY OF WHITEHEAD'S INFLUENCE ON ECOLOGY AND ECONOMICS

To some extent the potential of this was realized in biology. Whitehead's ideas were taken up by his colleague at Harvard, the ecologist William Morton Wheeler. Wheeler, emphasizing symbiotic relations and the emergence of communities as new patterns of integration, had a major influence on subsequent ecology in USA, particularly through the work of W.C. Allee (Worster, p.32off.). Whitehead also had a profound influence on the theoretical biology movement in Britain. C.H. Waddington, a leading member of this movement, questioned the abstractions of mainstream biology, including both the "environment" and the "gene". In taking up Whitehead's questioning of the abstraction of "environment", Waddington pointed out that organisms are not selected by a particular environment, but move in their environment, change it, and are selected for according to how they choose to respond to it (Waddington, r969a \& I969b). Adaptation must be thought of in a way that takes account of the organism's organic and conscious reactions to stress situations as well as contingencies such as what it has inherited and what environment it happens to be in. Examining epigenesis in the development of embryos, that is, the differentiation of cells and the generation of form, Waddington showed that there was no simply relationship between genes and phenotypes, with epigenesis involving development along emergent time paths (chreods) with different degrees of stability. Fitness can only be defined properly from the point of view of the population of active, striving organisms in various stages of development. So fitness cannot be defined in terms of genotypes, and there are even more difficulties involved in the attempt to speak of the fitness of single genes. Since any new species produces a more heterogeneous environment as a consequence of its interactions with the diverse phenotypes already in existence, it will generate the conditions for more species to evolve to fill the new ecological niches. And since the newer environments will be a function of an increasing number of phenotypes, there will be a tendency for more complex phenotypes to evolve which are capable of operating effectively in the more complex environments. This work was an important contribution of ecology and anticipated later complexity theory. Furthermore, Waddington extended his ideas to encompass humanity, and grappled with the major environmental problems facing us (Waddington, 1978).

Independently of both US ecologists and British biologists but influenced by both of them, Whitehead had a significant influence on Australian biology through the work of W.E. Agar and his student, Charles Birch. Birch became a major environmentalist and proponent of Whiteheadian thought, expounding his central

Handbook of Whiteheadian Process Thought Volume 1, Ed. Michel Weber and Will Desmond, (Frankfurt: Ontos Verlag, 2008). Pp.161-176. 
ideas on ecology and human ecology in The Liberation of Life, a work he wrote with John Cobb Jr. (I981).

Ecological economics is also realizing the potential of Whitehead's guidance. Ecological economics did not originate with Whiteheadian thought. It originated in the work of those who saw the incompatibility of the assumption by economists that growth could occur indefinitely and the second law of thermodynamics (MartinezAlier, 1990). However, one of the most important proponents of this argument was Nicholas Georgescu-Roegen who did draw on the work of Whitehead (GeorgescuRoegen, I97I, p.69ff.). Georgescu-Roegen attacked the "arithromorphism" and "arithromania" dominating modern thought, and economics in particular - the assumption that all concepts can be defined with the precision of numbers and the manic quest to understand the world entirely through such arithromorphic concepts (p.44f.; p.52). As he noted, "the complex notion of economic development has been reduced to a number, the income per capita. The dialectical spectrum of human wants (perhaps the most important element of the economic process) has long since been covered under the colorless numerical concept of "utility" for which, moreover, nobody has yet been able to provide an actual procedure of measurement" (p.52). This, he argued, is part of the pervasive tendency of economics to commit the fallacy of misplaced concreteness (p.32of.). To counter such tendencies, Georgescu-Roegen defended "dialectical" or "vague" concepts which cannot be precisely defined, arguing that these are essential for understand qualitative change which is ubiquitous in nature and society. Through a wide ranging analysis and critique of science in general and thermodynamics and economics in particular, Georgescu-Roegen exposed the flaws in neo-classical economics which had blinded it to qualitative change associated with historical and evolutionary processes and, most importantly, to the basic conditions of existence of the economy and of humanity. He introduced the notion of "entropic flow" to characterize the one-way flow beginning with resources and ending with waste.

This diagnosis of the core deficiencies of economic thought was embraced by Herman Daly, one of Georgescu-Roegen's students. Daly went on to become one of the founders of The International Society for Ecological Economics and its journal, Ecological Economics. Daly's first major paper in ecological economics proposed that economics be conceived as a life science (Daly, 1968). Arguing that ecology had abstracted nature from humanity while economics had abstracted humanity from nature, in each case failing to acknowledge that such an abstraction had taken place, Daly proposed a development of Leontief's input-output model of the economy for

Handbook of Whiteheadian Process Thought Volume 1, Ed. Michel Weber and Will Desmond, (Frankfurt: Ontos Verlag, 2008). Pp.161-176. 
ARRAN GARE: ECOLOGICAL ECONOMICS AND HUMAN ECOLOGY

overcoming these abstractions and uniting the two sciences. In later work, Daly identified a range of abstractions used by economists and then taken to be concrete reality. The clearest case is the neo-classical model of the economy as a circular flow between business and the public of money in one direction, and factors of production and goods in the other. This, Daly pointed out, is like abstracting the circulatory system of an organism from its metabolism in which it ingests food, transforms it and excretes waste, and then treating the circulatory system as the total organism (Daly, I996, p.193). Acknowledging "entropic flow" and acknowledging a range of distinctions ignored by neoclassical economists, Daly argued that we must aim at a steady-state economy, one which does not increase this entropic flow but concentrates on greater efficiency in the use of materials to produce a better quality of life (Daly, I977). Achieving such ends, Daly argued, involves bringing ethics (and implicitly, politics), back into the picture. We need to change values. We need to think about what the good life is and how to ensure that the market is controlled to maintain a steady-state and use resources efficiently to enable people to live a good life. Daly devoted considerable attention to what kinds of institutions would be necessary for these ends, arguing for institutions to prevent the concentration of income and the accumulation of excessive wealth, to limit births and to place quotas on resource depletion (1977, Chap.3). In the end, Daly called for biophysical equilibrium and moral growth (1977, Chap.8). Effectively, Daly (who often cites Hobson) has been reviving the social liberalism with which Whitehead was aligned.

Daly teamed up with John Cobb Jr. to write For the Common Good: redirecting the economy toward community, the environment, and a sustainable future (1989, 1994). To fully appreciate the significance of this title it is necessary to appreciate both the role ascribed to the common good by the social liberals and the vehemence with which this notion was attacked by the rational choice theorists associated with neo-classical economists and neo-liberalism. For the Common Good began with a thorough analysis of the abstractions ascribed misplaced concreteness by economists: the market, measurements of economic success, homo economicus and land. It called for a fundamental transformation of universities from academic disciplines to "thought in service of community". It called from a reorientation in thought from chrematistics (the study of money) to oikonomia, the study of the household, from individualism to person-in-community, from cosmopolitanism to communities of communities, from matter and rent to energy and biosphere. It offered policies for community in the United States, attacking the doctrine of free trade and promoting decentralization of political and economic power as real alternatives to the policies of the neo-liberals and

Handbook of Whiteheadian Process Thought Volume 1, Ed. Michel Weber and Will Desmond, (Frankfurt: Ontos Verlag, 2008). Pp.161-176. 
neo-conservatives. It also called for a new role for the USA, from world domination to national security. Finally, the work offered an Index of Sustainable Welfare as an alternative to Gross National Product as a measure of the true health of the economy (further developed by Clifford Cobb and John Cobb Jr., 1994). This gave a quite different picture of the US economy than measures of GNP, particularly after I980. "Economic welfare has been deteriorating for a decade," they noted, "largely as a result of growing income inequality, the exhaustion of resources, and unsustainable reliance on capital from overseas to pay for domestic consumption and investment" (p.507). All this was presented from the coherent perspective of Whiteheadian process philosophy. Apart from editing several anthologies on economics, ecology and ethics (1973, 1980, 1993) and a major statement and defence of his doctrines (1996) Daly has now produced a major textbook on ecological economics: Ecological Economics: Principles and Applications (2004), elaborating and further defending the arguments of For the Common Good.

Daly has also gone well outside the discipline of economics to produce with Thomas Prugh and Robert Costanza a major defence of strong democracy: The Local Politics of Global Sustainability (2000). Given Daly's efforts to construe the market as a part of the community which can at times be destructive and his concern to re-embed the market in the community, it was logical that he should have begun work on political institutions. And given his concern to revive communities, it was logical for him to embrace democracy as the form of power that involves people and thereby strengthens community. In developing these arguments, Daly and his colleague made an extremely important point. They noted that in USA environmentalism is a mile wide, but only an inch deep (p.go). In this work they provided an explanation for this. In practice people evaluate courses of action according to the role they are playing. If the role they are playing is that of consumers, they will tend to want the best they can get for their money. Any amount of moral growth will only have a minor impact on the decisions they make. But if the role they are evaluating courses of action from is that of governors, then they are likely to take a very different perspective. As the authors put it:

The citizen preference orientation is currently attenuated to the point of invisibility. Yet strengthening it would ineluctably bring people face-to-face with the problems of governance, including those of sustainability. Citizens brought into confrontation with the stark problems of governing their communities through handson participation ... would be educated in the sources of community troubles, in the origins of their way of life, and in the trade-offs that must be accepted in any collective

Handbook of Whiteheadian Process Thought Volume 1, Ed. Michel Weber and Will Desmond, (Frankfurt: Ontos Verlag, 2008). Pp.161-176. 
ARRAN GARE: ECOLOGICAL ECONOMICS AND HUMAN ECOLOGY

choice. With regard to sustainability issues in particular, self-governing citizens would more likely learn the ecological costs of their community's lifestyle and socioeconomic character (p.99).

This brings us back to the central insights of the social liberals which Whitehead's philosophy advanced but which were somehow lost sight of as the twentieth century progressed, the importance of democracy as both means and an end for the development of the full potentialities of people, as participants in institutions, to contribute to the common good, with the common good now extended to encompass the whole of nature.

\section{EGOLOGICAL ECONOMICS AND HUMAN ECOLOGY}

However, Daly's excursion into political philosophy highlights something fundamentally problematic about ecological economics as a discipline, a dimension of which both Daly and Cobb appear to be acutely aware. The evolution of universities has produced a tendency towards specialization that has fragmented knowledge. This has been conducive to the fallacy of misplaced concreteness. As noted, Daly and Cobb raised this issue in For the Common Good, suggesting reforms in universities to overcome this tendency by giving a place to cosmology, to interdisciplinary studies and efforts to grapple with global problems (p.364f.). It is difficult to overestimate how deep rooted this tendency to fragmentation of knowledge is, however, and some attention needs to be paid to the forces driving it. One of these is the quest to establish areas of expertise through which knowledge can be commodified and lucrative careers based (Levins and Lewontin, 1985, Chap. 8). This force has had a pervasive influence on the kinds of knowledge produced by these disciplines - they are heavily biased towards knowledge of how to control. Ecology, along with biology generally, has been affected by this. Donald Worster in his study of the history of ecology has traced this effect, noting how this has produced "bioeconomics" by which nature is construed as an economic system. As Hermann Reinheimer wrote:

Every day, from sunrise until sunset, myriads of [plant] laboratories, factories, workshops and industries all the world over, on land and in the sea, in the earth and on the surface soil, are incessantly occupied, adding each its little contribution to the general fund of organic wealth... (Worster, p.29I).

Worster noted Whitehead's efforts to overcome "one-eyed reason, deficient in its vision of depth" (p.316 from SMW 74) and the influence his notion of relational processes had on ecology. However, this influence was eclipsed. It was the bioeconomic vision which came to dominate. As Worster noted,

Handbook of Whiteheadian Process Thought Volume 1, Ed. Michel Weber and Will Desmond, (Frankfurt: Ontos Verlag, 2008). Pp.161-176. 
By the Ig6os, orthodox scientific thought was virtually monopolized by thermodynamics and bioeconomics. The organicists' vision of relatedness was confined to the eco-system model of the New Ecologists, who were quite as reductive in their way as Whitehead's bětes noires, the eighteenth century philosophes. From most professional circles, at least, the metabiological, idealizing tendencies of organicism had been firmly exorcised: Ecology at last had got its head out of the clouds, its feet on solid ground, and its hands on something to measure. ... It was thought that, to qualify as a field of objective knowledge, ecology could have no further dealings with the private, muddled realms of value, philosophy, and ethics (p.332).

Bioeconomics is the kind of knowledge which would enable ecologists to lay claim to an expertise in environmental management.

Daly did not formulate ecological economics in terms of the Whiteheadean strand of ecology as promoted by Wheeler, Waddington and Birch but in terms of bioeconomics. The influence of bioeconomics is manifest in the relative inattention by Daly to the exploration by organisms and to the possible contributions of their efforts to survive to the environments of other organisms, features of life to which Whitehead had drawn attention and which were amplified by Waddington. Without this, the challenge to social Darwinism presented by Whitehead and Waddington is weakened. Ecological economics as a science presents itself as a tool of management for governments. So even Daly's ecological economics is to some extent tainted by oneeyed reason, and perhaps partly for this reason has not fully realized its potential to subvert the prevailing neo-liberal culture.

What is needed to free science completely from one-eyed reason? Whitehead provided the basis for an answer to this when he characterized the task of a university as "the creation of the future, so far as rational thought, and civilized modes of appreciation, can affect the issue" (MT I7I). A science which no longer implicitly positions itself in relation to subjects considered outside the world and acting on it will have to reflexively acknowledge its development and its claims against rival orientations to living to be actively participating within the world being understood (Taylor, 2005, Prologue). This will be a science which explicitly relates itself to philosophy. While Daly has done this, it is also necessary in order to achieve such a link between the multiplicity of science disciplines and reflexive philosophy not just to encourage interdisciplinary work, as Daly and Cobb called for, but to develop a range of trans-disciplines that facilitate comprehension of the relationship of more specific trans-disciplines, disciplines and sub-disciplines to each other. To some extent the humanities, both philosophy and history, can and should play this role, but more is

Handbook of Whiteheadian Process Thought Volume 1, Ed. Michel Weber and Will Desmond, (Frankfurt: Ontos Verlag, 2008). Pp.161-176. 
ARRAN GARE: ECOLOGICAL ECONOMICS AND HUMAN ECOLOGY

needed. Ecological economics itself has been presented with some justification as a trans-discipline. But to relate the evolution of modern civilization to the broader evolutionary history of nature and humanity, to relate the study of markets not only to ecological processes and institutions associated with economic activity but to other social forms and institutions of diverse societies and civilizations, to identify the ecologically sustainable and ecologically unsustainable social forms, to comprehend and align people in relation to the power struggles within and between societies and to efforts by people to understand and control their destinies, and to reflexively acknowledge the participation of science in such efforts, to evaluate all these and orient people for action, requires more than philosophy, history and ecological economics; it requires human ecology.

While in the past human ecology has floundered in the face of the complexity of the theoretical problems confronting it, having to deal both with ecological complexity and the complexity of social dynamics simultaneously (Kormondy \& Brown, I998), recent work in theoretical ecology has provided the means to incorporate the "population-community approach" with its focus on the interaction between organisms and the formation of communities, with the "bioeconomic" "processfunctionalist approach" with its focus on energy flows and nutrient cycles (Allen, T.F.H and Starr, Thomas B., I982; O’Neill et.al., I986; Allen and Hoekstra, I992), and to extend this to encompass humanity and its history (Dyke, I988; Gare, 200ob \& 2002; Allen et.al., 2003). This theoretical perspective is based on a form of hierarchy theory which does not derive from Whitehead; but it is a form of process thinking consistent with his process metaphysics (Gare, 2000c). One of its implications is that the very being of any entity as self-creating is taken to involve self-constraining. This means that when it comes to humans, the constraints associated with ethics and politics are no longer seen as extrinsic to people but as an aspect of their self-creation.

While human ecology formulated in this way is consistent with the ecological economics of Daly and Cobb, the commitment to democracy and the conditions for achieving it can be made even stronger (Gare, 2004). It provides a broader framework for examining what is required to achieve democracy throughout the world and presents the struggle to address global environmental problems in a more positive way. Daly defines the basic ethical principle of his ecological economics as: "We should strive for sufficient per capita wealth - efficiently maintained and allocated, and equitably distributed - for the maximum number of people that can be sustained over time under these conditions" (Daly, 1996, p.220). This is a moralistic injunction which tends to assume a disjunction between how people should behave and their self-

Handbook of Whiteheadian Process Thought Volume 1, Ed. Michel Weber and Will Desmond, (Frankfurt: Ontos Verlag, 2008). Pp.161-176. 
interested inclinations. The social liberals, and Whitehead following them, tended to think more in terms of characterizing the good life and working out the conditions for achieving it. They upheld a vision of life in which the pursuit of highest ends requires the recognition and appreciation of others, holding that a life of self-indulgence is not only destructive of others but intrinsically deficient. The quest to be able to live a life not destructive of nature, other people and the future is not a curtailment of one's freedom but is central to the pursuit of liberty, the condition under which people, both individuals and communities, can develop their full, unique potentials to freely contribute to the common good. Developing such a trans-discipline and such an outlook and using this to revive the tradition of social liberalism is only in its early stages and manifests the continued importance of Whitehead as a guide for the elaboration of new abstractions. Human ecology will be subject to the usual pressures of universities to develop as another specialist discipline to provide particular area of expertise for environmental management rather than the perspective needed by citizens to create and sustain a genuinely democratic society. The prospects for success in this regard are intimately related to the prospects of process thought generally, and this in turn will largely determine the prospects for civilization and the future of humanity.

\section{BIBLIOGRAPHY:}

Allen, T.F.H. and Starr, Thomas B. 1982. Hierarchy: Perspectives for Ecological Complexity. (Chicago, University of Chicago Press).

Allen, Timothy F. H. and Hoekstra, Thomas W. 1992. Toward a Unified Ecology. (New York, Columbia University Press).

Allen, T.F.H., Tainter, Joseph A., \& Hoekstra, Thomas W. 2003. Supply-Side Sustainability. (New York, Columbia University Press).

Amadae, S.M. 2003. Rationalizing Capitalist Democracy. (Chicago, University of Chicago Press).

Arthur, Brian. 1994. Increasing Returns and Path Dependence in the Economy. (Ann Arbor, University of Michigan Press).

Barton, Ruth, "John Tyndall, Pantheist: Rereading the Belfast Address", Osiris, $2^{\text {nd }}$ series, I987, 3, III-134.

Boucher, David ed. 1997. The British Idealists. (Cambridge, Cambridge University Press).

Handbook of Whiteheadian Process Thought Volume 1, Ed. Michel Weber and Will Desmond, (Frankfurt: Ontos Verlag, 2008). Pp.161-176. 
Birch, Charles and Cobb, John B. Jr. I98I. The Liberation of Life: From the Cell to the Community. (Cambridge: Cambridge University Press).

Bunker, Stephen G. I988. Underdeveloping the Amazon, Extraction, Unequal Exchange, and the Failure of the Modern State. (Chicago, University of Chicago Press).

Clarke, Peter. 1978. Liberals \& Social Democrats. (Cambridge, Cambridge University Press).

Cobb, Clifford and Cobb, John Jr. 1994. The Green National Product: A Proposed Index of Sustainable Economic Welfare. (Lanham MD., University Press of America).

Constanza, Robert ed. I99I. Ecological Economics. (New York, Columbia University Press).

Daly, Herman E. 1968. "On Economics as a Life Science", fournal of Political Economy, $76,392-406$.

Daly, Herman E. ed. 1973. Toward a Steady-State Economy. (San Francisco, Freeman).

Daly, Herman E. 1977, 1991. Steady-State Economics. (San Francisco, Freeman).

Daly, Herman E. ed. I980. Economics, Ecology, Ethics: Essays Toward a Steady-State Economy. (San Francisco, Freeman).

Daly, Herman E. and Townsend, Kenneth N. eds. 1993. Valuing the Earth: Economics, Ecology, Ethics. (Cambridge, Mass., MIT Press).

Daly, Herman E. and Cobb, John B. Jr, I989, I994. For the Common Good: Redirecting the economy toward community, the environment, and a sustainable future. (Boston, Beacon Press).

Daly, Herman E. 1996. Beyond Growth: The Economics of Sustainable Development, Boston, Beacon Press.

Daly, Herman E. and Farley, Joshua, 2004. Ecological Economics: Principles and Applications. (Washington, Island Press).

Dyke, C. I988. The Evolutionary Dynamics of Complex Systems: A Study in Biosocial Complexity. (New York; Oxford University Press).

Friedman, Milton. 1953. Essays in Positive Economics. (Chicago, The University of Chicago Press).

Gare, Arran. June, I999. "Speculative Metaphysics and the Future of Philosophy: The Contemporary Relevance of Whitehead's Defence of Speculative Metaphysics", Australasian Fournal of Philosophy, 77, 2, 127-I 45.

Gare, Arran. 2000a. "Systems Theory and Complexity", Democracy and Nature. 6, 3, 327-339.

Handbook of Whiteheadian Process Thought Volume 1, Ed. Michel Weber and Will Desmond, (Frankfurt: Ontos Verlag, 2008). Pp.161-176. 
Gare, Arran. 20oob. "Is it Possible to Create an Ecologically Sustainable World Order: The Implications of Hierarchy Theory for Human Ecology", International Journal of Sustainable Development and World Ecology. 7, 4, 277-290.

Gare, Arran. 2000c. "Human Ecology, Process Philosophy and the Global Ecological Crisis", Concresence: The Australasian Fournal for Process Thought: An Online Fournal, I, I.

Gare, Arran. 2002. "Human Ecology and Public Policy: Overcoming the Hegemony of Economics", Democracy and Nature. 8, I, I3 ${ }^{\mathrm{I}}$-I4I.

Georgescu-Roegen, Nicholas. 1971. The Entropy Law and the Economic Process. (Cambridge, Harvard University Press).

Gowdy, John and Erickson. 2005. "The Approach of Ecological Economics", Cambridge Journal of Economics, 29, 207-222.

Green, T.H. 1986. Lectures on the Principles of Political Obligation and Other Writings. ed. Paul Harris and John Morrow. (Cambridge, Cambridge University Press).

Green, T.H. 2003. Prolegomena to Ethics. ed. David O. Brink. (Oxford, Clarendon).

Groh, Dieter and Sieferle, Rolf-Peter. Autumn, ig8o. "Experience of Nature in Bourgeois Society and Economic Theory", Social Research. 3, 557-58I.

Harcourt, G.C. I982. The Social Science Imperialists, (London, Routledge \& Kegan Paul).

Harman, P.M. 1998. The Natural Philosophy of James Clerk Maxwell. (Cambridge, Cambridge University Press).

Hobhouse, L.T. igı I. Liberalism, (London, Williams \& Norgate).

Hodgson, Geoffrey M. 1999. Evolution and Institutions: On Evolutionary Economics and the Evolution of Economics. (Cheltenham, Edward Elgar).

Hodgson, Geoffrey M. 2001. How Economics Forgot History. (London, Routledge).

Hollis, Martin and Nell, Edward J. 1979. "Two Economists" Philosophy and Economic Theory. ed. Frank Hahn and Martin Hollis. (Oxford, Oxford University Press).

Jevons, W. Stanley. 1924. The Theory of Political Economy. $4^{\text {th }}$ ed., (London, Macmillan).

Kormondy, Edward J. and Brown, Daniel E. 1998. Fundamentals of Human Ecology. (Englewood Cliffs, Prentice Hall).

Kregel, J.A. 1975. The Reconstruction of Political Economy. $2^{\text {nd }}$ ed. (London, Macmillan).

Levins, Richard and Lewontin, Richard. 1985. The Dialectical Biologist. (Cambridge, Harvard University Press).

Lewontin, R.C., Rose, Steven and Kamin, Leon J. 1984. Not in Our Genese: Biology, Ideology, and Human Nature. (New York: Pantheon Books).

Lowe, Victor. 1985. Alfred North Whitehead: The Man and His Work, Volume I: ı86ı-I9ro. (Baltimore, John Hopkins University Press).

Handbook of Whiteheadian Process Thought Volume 1, Ed. Michel Weber and Will Desmond, (Frankfurt: Ontos Verlag, 2008). Pp.161-176. 
ARRAN GARE: ECOLOGICAL ECONOMICS AND HUMAN ECOLOGY

Martinez-Alier, Juan. I99o. Ecological Economics: Energy, Environment and Society, (Oxford, Blackwell).

Mirowski, Philip ed. I986. The Reconstruction of Political Economy. (Boston, Luwer-Nijhoff). Mirowski, Philip ed. 1994. Natural Images in Economic Thought. (Cambridge, Cambridge University Press).

Mirowski, Philip. 2002. Machine Dreams: Economics Becomes a Cyborg Science. (Cambridge, Cambridge University Press).

Murdoch, Walter. 1903. The Struggle for Freedom. (Melbourne: Whitcombe \& Tombs).

Nell, Edward J. 1980. Growth, Profits \& Property. (Cambridge, Cambridge University Press).

O’Neill, R.V., DeAngelis, D.L., Waide, J.B., and Allen, T.F.H. I986. A Hierarchical Concept of Ecosystems. (Princeton, Princeton University Press).

Ormerod, Paul. 1994. The Death of Economics. (London, Faber and Faber).

Osborne, David and Gaebler. 1993. Reinventing Government: How the Entrepreneurial Spirit Is Transforming the Public Sector. (Harmondsworth: Penguin Books).

Peirce, Charles Sanders. 1955. Philosophical Writings. (New York, Dover).

Pibram, Karl. 1983. A History of Economic Reasoning. (Baltimore, John Hopkins University Press).

Prugh, Thomas, Costanza, Robert and Daly, Herman. 200o. The Local Politics of Global Sustainability. (Washington, Island Press).

Richards, Robert J. 2003. The Romantic Conception of Life. (Chicago, The University of Chicago Press).

Ritchie, David G. 1983. Darwin and Hegel. (London, Swan Sonnenschein \& Co.).

Ritchie, David G. I902. The Principles of State Interference. (New York, Freeport).

Røpke, Inge. 2004. "The early history of modern ecological economics", Ecological Economics. 50, 293-314.

Røpke, Inge. 2005. "Trends in the development of ecological economics from the late I980s to the early 200os", Ecological Economics. 55, 262-290.

Roosevelt, Frank, 'Cambridge Economics as Commodity Fetishism', The Review of Radical Political Economics, 7(4) Winter 1975.

Söderbaum, Peter. 200o. Ecological Economics. (London, Earthscan).

Spash, Clive L. 1999. "The Development of Environmental Thinking in Economics" Environmental Values. 8, 413-35.

Spencer, Herbert. 1972. On Social Evolution, ed. J.D.Y. Peel. (Chicago, University of Chicago Press).

Handbook of Whiteheadian Process Thought Volume 1, Ed. Michel Weber and Will Desmond, (Frankfurt: Ontos Verlag, 2008). Pp.161-176. 
Spencer, Herbert. 1969. The Man Versus the State, [1884]. ed. Donald Macrae. (Harmondsworth, Penguin).

Taylor, Peter J. 2005. Unruly Complexity: Ecology, Interpretation, Engagement. (Chicago, University of Chicago Press).

Waddington, C.H. Ig6ga. "Paradigm for an Evolutionary Process" in Towards a Theoretical Biology, 2, Sketches, G.H.Waddington ed. (Edinburgh, University Press of Edinburgh) I969a, pp.105- I2

Waddington, C.H. ig6gb."The Theory of Evolution Today" in Beyond Reductionism: The Alpbach Symposium, Arthur Koestler \& J.R. Smythies eds. London, Radius Books, Hutchinson, pp. 357-395.

Waddington, C.H. 1978. The Man-Made Future. (New York, St Martins).

Whitehead. Alfred North. I925. Science and the Modern World (SMW), (N.Y.: Free Press).

Whitehead. Alfred North. 1929 (Corrected Edition, 1978). Process and Reality (PR), (N.Y.: Free Press.)

Whitehead. Alfred North. 1938. Modes of Thought (MT) (N.Y.: Free Press).

Whitehead. Alfred North. 1947. Essays in Science and Philosophy (ESP), (N.Y. Philosophical Library).

Wilson, Edward O. 1975. Sociobiology: The New Synthesis. (Cambridge Mass.: Harvard Uni. Press).

Worster, Donald. 1994. Nature's Economy: A History of Ecological Ideas, $2^{\text {nd }}$ ed., (Cambridge: Cambridge University Press).

Handbook of Whiteheadian Process Thought Volume 1, Ed. Michel Weber and Will Desmond, (Frankfurt: Ontos Verlag, 2008). Pp.161-176. 